(昭和 33 年 11 月 14 日受理)

反応性染料によるビスコースレーヨンのスキン染色

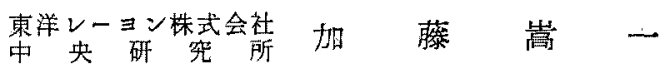

\title{
REACTIVE DYE STAINING FOR DIFFERENTIATION OF SKIN AND CORE OF VISCOSE RAYON FIBERS
}

\author{
By Koichi Kato \\ (Central Research Laboratories, Toyo Rayon Co, Ltd., Ōtsu, Japan)
}

A new technique for staining the skin of viscose rayon cross sections is described, where Procion Black HGS, a sort of dyes marketed by ICI as chemically reactive dyestuff for cellulose fibers. is used combined with urea and soda ash. The technique is found to furnish a staining entirely selective for the skin area without requiring any particular differentiation procedure.

This staining may be of great significance practically as well as theoretically, since it depends upon a chemical reaction between the dye and cellulose, i. e. upon a mechanism quite different from that of other usual dye techniques.

The same staining procedure has been applied to other fibers, not only cellulosic, but also protein as well as synthetic. Interestingly enough, it has been found that wool fibers show a bilateral staining, while Vinylon exhibits a skin-core type differentiation. (Received November 14, 1958)

\section{1. 緒要}

最近せルロース䋐維に対して化学区灾的に結合して堅 ろろな染色を与える一群の染料が市場に現われ注目を浴 びている。英国 ICI 社のProcion 染料，スイス Ciba 社 の Cibacron 染料, ドイッ Hoechst 社の Remazol 染 料等がこれに属する。その染色機構についてはすでに多 数の報告（例えば 1 4) があるが，要するにアルカリ の存在に批いてせルースの水酸基と次の上5に反応す るるのと考宎られている。

$\mathrm{NaSO}_{3}-\mathrm{D}-\mathrm{Cl}+\mathrm{HO}-\mathrm{Cell} \rightarrow \mathrm{NaSO}_{3}-\mathrm{D}-\mathrm{O}-\mathrm{Cell}+\mathrm{HCl}$

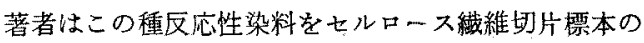
染色儿応用することを陚み，その結果として Procion Black HGS を用いてビスコースレーヨンのスキン・コ ア搆造の染めわけたすぐれた成果を得ることができた。

従来この目的に用いられている標本染色法に関して は，前報 (5)に抋いて代表的なるのを紹介し比較考察を 加它た。本報に記述する Procion Black 法はこの染めわ けの機構において直接染料（6１0） または篮基性染料 (11〜13)を用いる方法と全然異ることは明らかである が，セルッースの䢱元性に基ずく一種の化学的染色法で める銀染色法 $(14,15)$ とも異るるのである。 本法は以下に述べる通り全く選択的なスキン染色であ
つて, 從来のどの染色法よりも操作が簡単かつ迅速であ るからルーチン試験法として適当している。しかし同

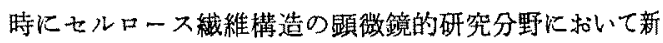
しい意味を持つた知見を与光るもよしてとの心用の成 果が期待される。

\section{2. 切片標本染色方法}

切片標本としては厚さ5ミクロン内外のるのを用い る。䇿準パラフィン法なたは寒天パラフィン法によつて 作製し，完全に脱包埋すること。

染料液は次のよ5に調製する。すなわら少量の蒸留水 に Procion Black HGS 10g および尿素7g を加熱しつ つ溶解する。この溶液が冷却したのちソーダ死 $2 \mathrm{~g}$ を加 え, 蒸留水で $100 \mathrm{~g}$ にる。この染料溶液は室温で長く 保存でる。

染色操作は次の通りである。すなわら划片標本上比上 記染料溶液を充分量のせ，小火焰恋たは熱板上に固いて 静かに加温する。3〜5 分間でよい。气の政染料液が蒸 発乾固することのない上ら注意する。水洗して過剩の染 料を洗い报とす。適当な万法で封入する。

上記染色操作の結果第 1 図強力ビスコースレーヨンの 例に見られる通り，スキン層が選択的に濃く染色され， コアは染まらない状態の標本が得られる。従つてここで 


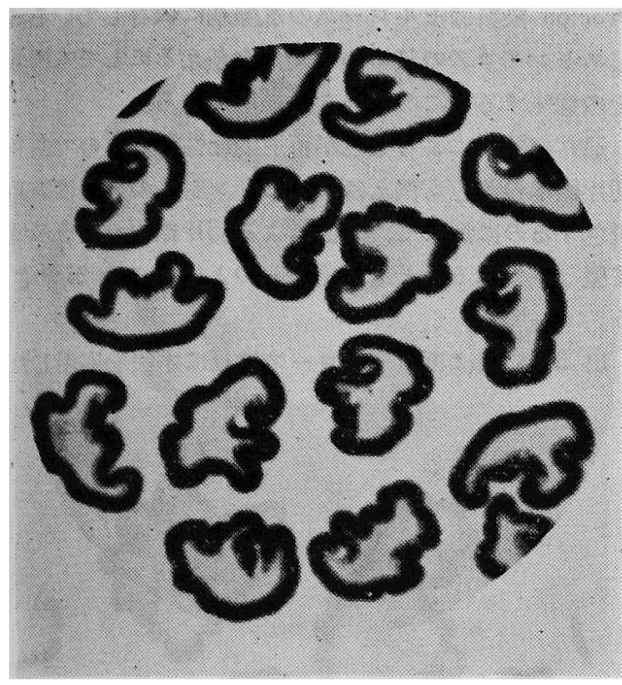

Fig. 1 Typical skin staining in a tire cord rayon, obtained by the Procion Black technique described in this paper. $(800 \times)$

性何らの分色操作を必要としない。染色結果が染色時間 の多少の変動によつても全然左右されない点はルーチン 法としての長所であろ5。

\section{3. 染色法についての説明}

Procion 染料のいわゆる Cold Type のひのおよび $\mathrm{H}$ Brand のもの数種についてその適性を比較調查した結 果, 上記 Procion Black HGS が最適であることを認め た。他のるのは一般に顕微鏡標本用としては切片への染 色が淡すぎること, 拉よびコア層にもある程度染着が起

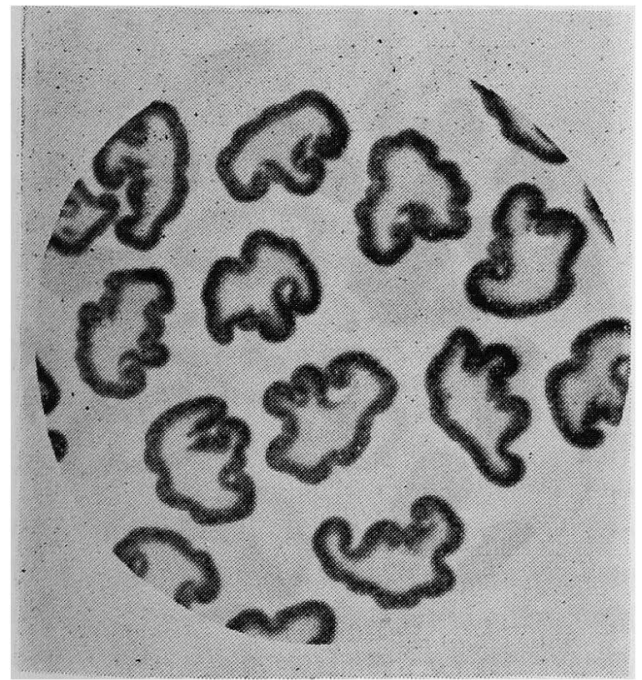

Fig. 2 Reduction in staining due to the lowered dye concentration $(1 / 8)$. $(800 \times)$
り，そのためスキン・コアのコントラストが低くなるこ とが共通の欠点であつた。

なお, Cibacron Black BG は大体 Procion Black HGS に近い成績を与えるが, Remazol Black B はコア が染まるので不適当であつた。Procion Black HGS は 反応性の低いH Brand であるため，かえつてそのアル カリ性溶液の安定性がよく保有に耐える利点がある。

染料の固定反応を起させるために必要なアルカリとし て同一濃度 $(2 \%)$ で比較すると重曹, ソーダ灰, 燐酸 三ソーダはこの順に $\mathrm{pH}$ が高くなり, それ応じて染着 も強くなる。重曹では少し染色が淡すぎる感があり, 他 方憐酸三ソーダでは染色過度となりやすい。溶液の安定

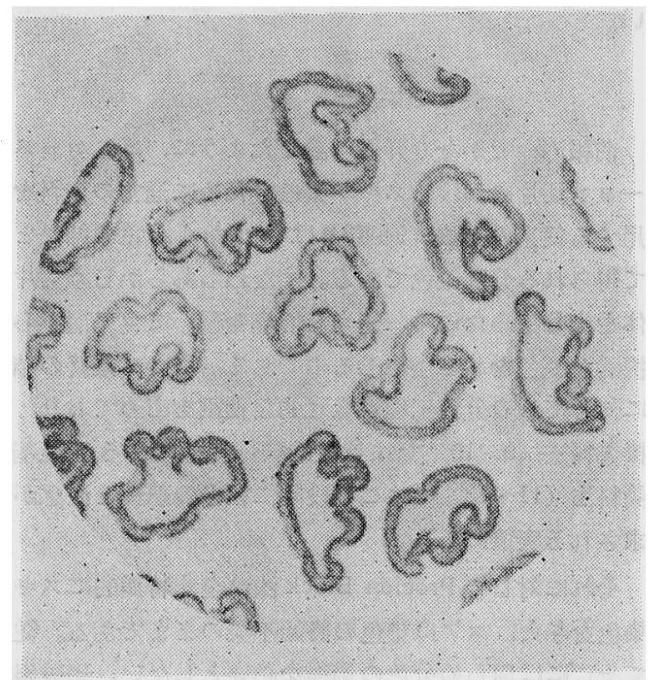

Fig. 3 Faint staining upon no heating. $(800 \times)$

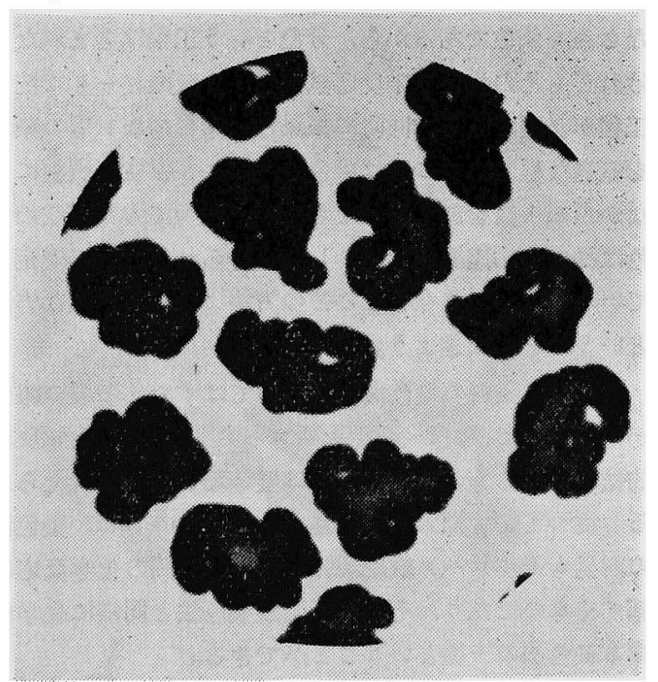

Fig. 4 Excessive staining due to having the mounted dye solution dried up. $(800 \times)$ 
性をも考虑してソーダ灰が適当と考学られた。

染料濃度を上記組成（10\%）より減少して行くとそれ に応じてスキンの染着が低下する。第 2 図は標準組成の $1 / 8$ 濃度の場合である。第 1 図と比較されたい。

染料溶液を盛つた切片標本はこれを小火焰または熱板 上で加熱することが必要である。Procion Black HGS はさもないと十分な固定反応を起さない。第 3 図は常温 のまま 3 分間保つた標本の染着状態を示するのである。

加温は 3〜5 分間でよく, それ以上膡いても特に変化 が見られない。その場合染料液が蒸発乾固するに至ると コアにも染色が起り全面濃染してみぐるしいものとな る。第 4 図はその状態を示す。厳に注意せねばならな い。

\section{4. 考察}

前報（5）でかなり詳細に論じたよ5に，ビスュースレ 一ヨン切片におけるスキン染色のために通常の染料を使 用する従来の方法 (9～13) は例外なく分色の結果とし て得られる分別染色である。すなわちあらかじめ切片全 体を十分染ぬたのち, 適当な溶媒を用いてコア層から選 択的な脱色をおこなわせるのである。従つて最終の結果 に対してこの分色工程が決定的な役割を占めており, 直 接染料法 $(9 ， 10)$ では比較的操作容易であるが塩基性 染料法（11〜13）ではこの段階に相当の熟練と注意が要 求される実情にある。

それに対して Procion Black 法は全く特異的にスキン 染色を与光，コアは染色の終始不染のままである。従つ てそこには何らの分色の過程を必要としない。硝酸銀試 薬を用いる銀染色法 $(14 ， 15)$ 任化学反応に基く特異的 なスキン染色であるから，分色という工程は含まれない けれどもその代わり未反応試薬をチオ硫酸ソーダで洗 5 工程が必要である。同時に銀染色の場合スキン層の染色 を適当な程度に保つには染色時間および温度の調整に少 なからぬ手数を加えねばならない。従つて本報記載の染 色は操作が迅速簡便でありしかも得られる結果が安定し ている点に括いて今までのどの方法よりもすぐれた方法 ということができよう。

Procion 染料の染色機構についてはすでに多数の報告 がなされて扣り（1４），七ルロースとの間の化学反応 的結合によるものであることは疑いないことと考えられ る。従つて切片標本に適用された Procion Black 染色法 の所見もセルロース繊維切片と染料との間の化学反応に 基ずくものであり，その点上記銀染色法と同様に化学的 標本染色法の一種といらことができる。

しかしその反応機構に拉いて銀染色法はセルロースの 還元性末端基に依有するものである（15）のに対して
Procion 染料はセルロースの水酸基に依存している。同 じスキン・コアの染めわけ効果を与えるにしても両者は その意味するところが異なるわけである。

通常の染料による染色が可逆的な性質のものであり， 切片標本の染色も例えばグリセりン封入の形では容易に 脱色するのに反して，本法による切片標本の染色が極め て堅ろらであることる特色の一つといらことができよ 5 。

第 5〜8 図は再生セルロース緘維に本法を応用した例

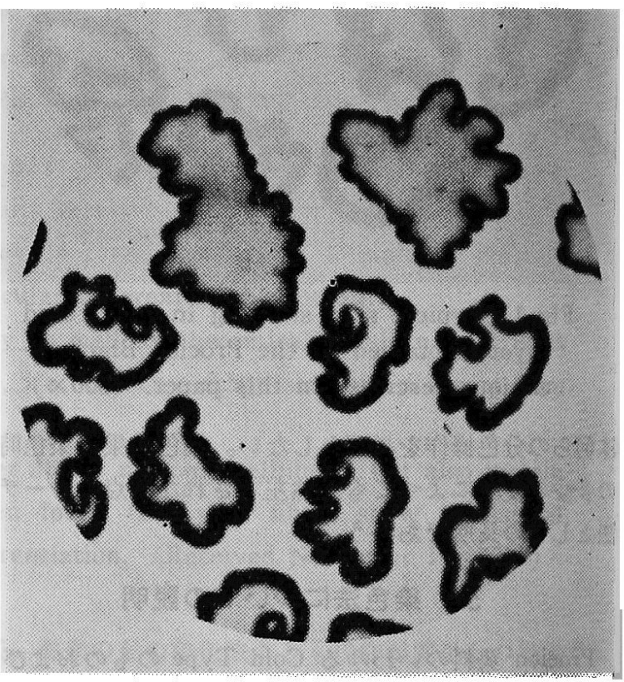

Fig. 5 A textile viscose rayon compared with a tire cord rayon. $(800 \times)$

The core of the former is also showing a slight staining.

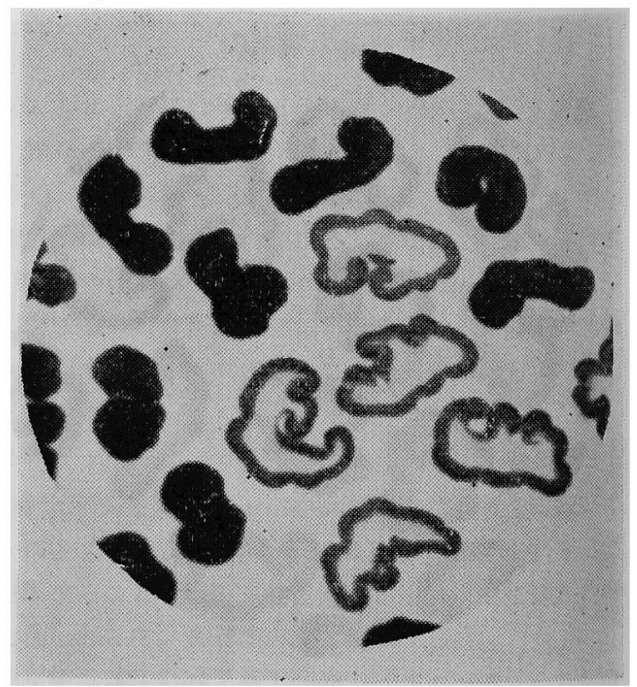

Fig. 6 An all-skin type rayon compared with a tire cord rayon. $(800 x)$ 


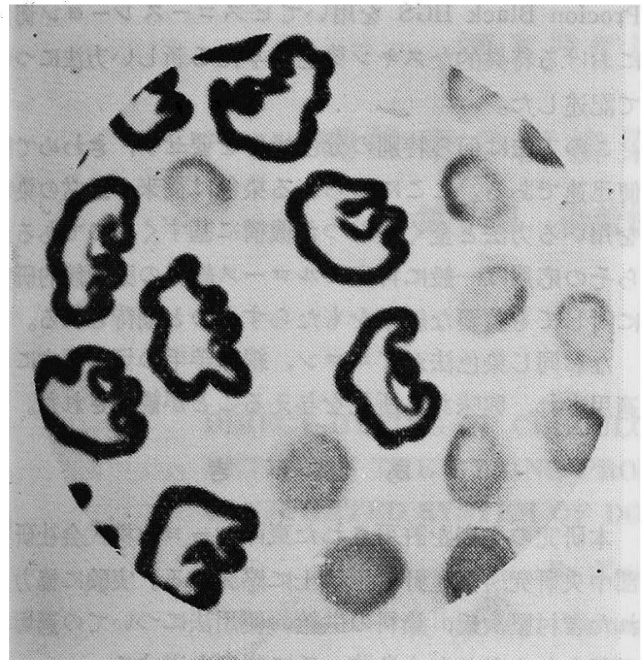

Fig.7 A cuprammonium rayon compared with a tire cord rayon. (800)

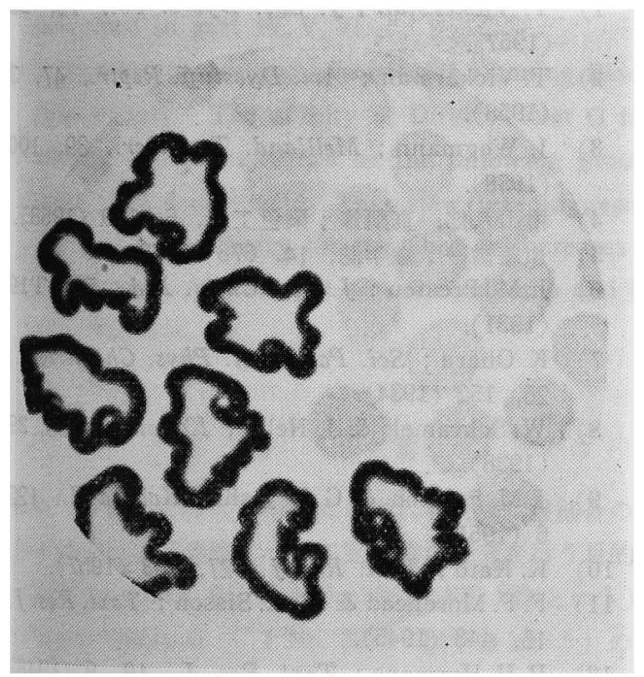

Fig. 8 A sample of Fortisan compared with a tire cord rayon. $(800 \times)$

であつて, 典型的なスキン：コア効果を示す強力レーヨ ン陚料が対照として同時包埋されている。

再生セルロース瀻維の顕微鏡的研究法として切片染色 性の観察は少なからぬ意義を有するものである（5）が 従来の染料を用いる方法怙よび銀染色法のほかに，明ら かに異つた染色機構に基ずく方法がここに与えられたわ けであるから，今後の応用によつてこの方面に新しい知 見が得られ，ビスコースレーヨンのスキン・コアの問題 や一般にセルロース瀻維の構造に関して一層の解明が得 られることが期待される。しかしながら第 5〜8 図に見 る通り Procion Black 染色の結果が染色の機構を異に
する染料法ならびに銀染色法の結果とほとんど完主に一 致することはむしろ意外の感がある。

なお，第 7 図ベンベルグと第 8 図のブォーチザンはこ の場合共通して低い染色性を示しているが両者の性質は 実は前者がコアに近く，後者がスキンに近いのである (5)。このような Procion Black 不染部分に対しては 適当な染料による対比染色を施して染着の難易による差 を検出し得るよう考穼するのが望ましい。

\section{5. 他種織維への応用}

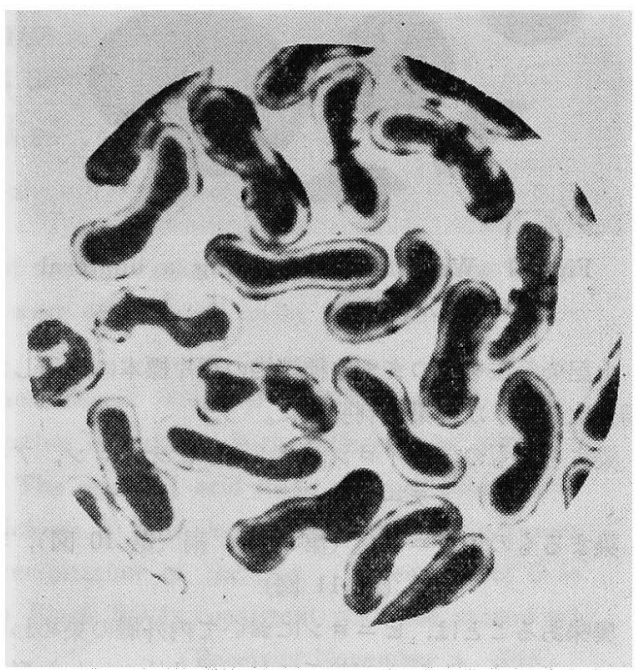

Fig. 9 A sample of Vinylon with skin-core differentiatian, the core being selectively stained. $(800 \times)$

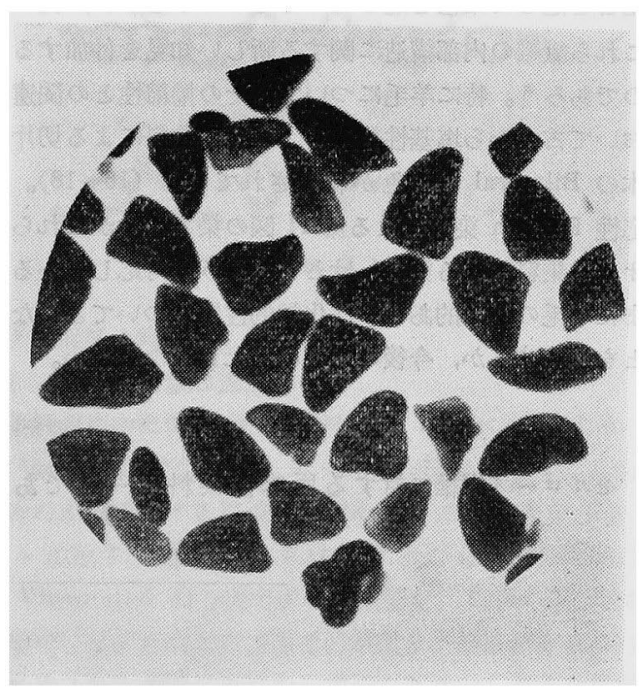

Fig. 10 Silk fibroin filaments, showing a uniform staining. $(800 \times)$ 


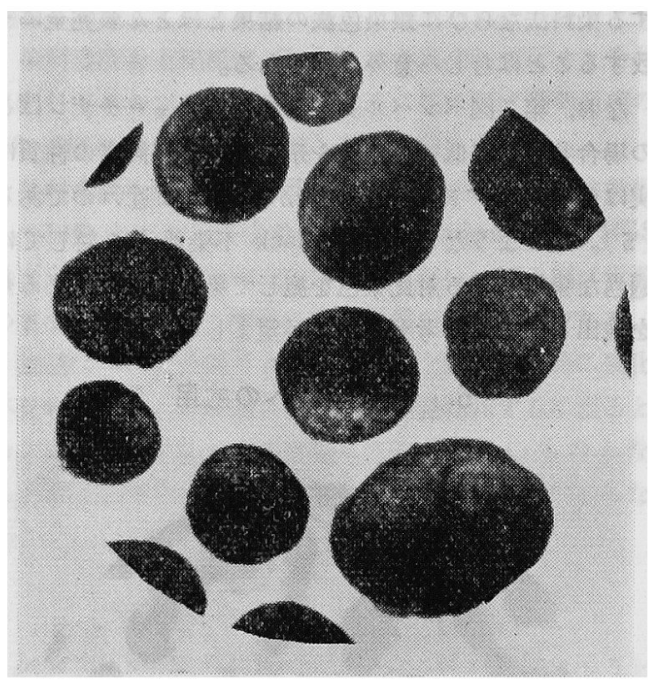

Fig. 11 Wool fibers, showing a bilateral staining. $(800 \times)$

上記染色法をそのまま他種繊維の切片標本に応用した 場合次のような結果が判明した。

染まらなもの：ナイロン, テトロン, オーロン, アセ テート

染まるもの：ピニロン(第 9 図), 絹(第 10 図), 羊 毛 (第 11 図)

興味あることは，ビニロンにおいて内外層の染めわけ が起つていること扰よび羊毛に拈いて bilateral な形の 染めわけの観察されることである。これらの繊維につい てもProcion 染料はそれぞれの反応性水酸基と化学的 結合を通して染色を起しているものと予想され, 従つて これら繊維の内部構造に関する新しい知見を付加するる のであう5。特に羊毛についてはその港樎性との関連に おいて古くから塩基性染料扣よび酸性染料による切片標 本の Bilateral な染色が報告されている $(16 \sim 18)$ 。反 応性 Procion 染料による第 11 図の染めわけがこれらイ オン性染料による染めわけとどのよ5に対応しているか また羊毛の物理的あるい性学的性質についてどんなこ とを意味するか，今後の研究にまたねばならない。

\section{6. ま と め}

セルロース紼維に対する反応性染料の一種である
Procion Black HGS を用いてビスコースレーヨン切片 に拈ける特異的なスキン染色を与える新しい方法につい て記述した。

この方法は何ら特別の分色操作を要せず，きわめて簡 便迅速である。ここに得られる染色は彷来の通常の染料 を用いる方法と全く異なつた機構に基ずくものであるか らその応用は一般に再生セルロース繊維の顕微鏡的研究 に対しても重要な結果をもたらするのと期待される。

な打同じ染色法がビニロン, 絹, 羊毛の切片標本にも 適用され，興味ある所見を与学ることが観察された。

\section{あとがき}

本研究の発表を許可された東洋レーヨン株式会社研究 部中央研究所長星野孝平博士に感謝する。実験に協力さ れた吉村堅次氏，染料の供給，使用法についての適切な 示唆を与えられた小島弥一氏に謝意を表する。

文献

1) T. Vickerstaff ; J. Soc. Dyers. Co., 73, 237 (1957).

2) T.Vickerstaff ; Am. Dyestuff. Reptr., 47, 33 (1958).

3) J. Wegmann ; Melliand. Textilber., 39, 1006 (1958).

4) 檜山八郎, 真鍋修; 染色工業, 6, 169 (1958).

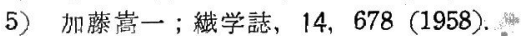

6) J. M. Preston ; J. Soc. Chem. Ind., 50, T199 (1931).

7) K. Ohara ; Sci. Pap. Inst. Phys. Chem, Res., 25, 152 (1934).

8) W. Schramek \& J. Helm ; Kolloid-Z., 85, 291 (1938).

9) J.M. Preston \& G. D. Joshi ; Kolloid-Z., 122, 6 (1951).

10) K. Kato; Text. Res. J., 27, 803 (1957).

11) F. F. Morehead \& W. A. Sisson ; Text.Res. J., 15, 443 (1945).

12) P. H. Hermans ; Text. Res. J., 18, 9 (1948),

13) W. R. Berry ; Text. Res. J., 24, 397 (1954).

14) A. N. J. Heyn ; Fiber Microscopy, p. 201, New York (1954).

15) K. Katon; Text. Res. J. (in press)

16) K. Ohara; Melliand Textilber., 19, 407(1938).

17) M. Horio and T. Kondo ; Text. Res. J., 23, 373 (1953).

18) E. H. Mercer ; ibid., 23, 388 (1953). 